\title{
Differentiating Hamlet: Ophelia and the Problems of Subjectivity
}

RICHARD

FINKELSTEIN

Summary: By considering the positions Hamlet explores with regards to the nature of intention, the nature and acquisition of knowledge, the effectiveness of reason, and their relation to psychological integrity, the author of this paper argues that Shakespeare evaluates the play's participation in the project of defining subjectivity. Ophelia's role in its inquiry provokes questions which callenge many of Hamlet's, Claudius' and Polonius' assumptions about subjectivity, which are often aligned. The play sustains both object relations methods and post-modern constructions of the self because Hamlet's arguments dominate but are also critiqued.

Derhaps more than any other Shakespeare tragedy, Hamlet promotes arguments that the Renaissance idealizes individualism and a subjectivity bounded by reason and knowledge. The play's status both constructs and is generated by psychological concepts under attack in post-modern discourse, and derives from identifying the play's inquiry with the interests of its hero. ${ }^{1}$ Hamlet actually contains a polyphony of voices speaking to these issues. We do not always hear them because the play pulls us towards identifying almost exclusively with Hamlet himself. C. L. Barber and Richard Wheeler cogently summarize this pressure when noting that "In Hamlet, we are invited to identify with the hero at the expense of a comprehensive ironic perspective; there is no adequate basis for an outside, controlling perspective. The single-sided attitude it creates toward its hero is one of the striking differences between Hamlet and the ensuing tragedies."2 The hero's dominating presence - even the sheer volume of his 
lines - overwhelms arguments which emerge more forcefully in Shakespeare's other mature tragedies, especially Lear, and differently, in Antony and Cleopatra. However, alternative views are there. As readers or spectators we move towards identifying with the hero. But as Christy Desmet has shown, Ophelia's rhetoric transforms us into judges who praise or blame Hamlet, disrupting that central identification. ${ }^{3}$

The figures of Ophelia and, to a lesser extent Gertrude, drive a wedge between us and Hamlet, and challenge arguments about subjectivity inspired by his forceful presence. Ophelia provokes questions about psychology and epistemology which implicitly frame discussions of subjectivity. She can stop the circulation of cultural energy through these frameworks (literally so in Act 4), so that she often serves the "negative function" Kristeva assigns women: if not rejecting the existing state of society, using différance to expose alternatives for its accepted constructions. ${ }^{4}$ Hamlet, though, also moves beyond difference. As Nancy Chodorow has recently argued, feminist political and cultural theories risk undervaluing psychology, itself concerned with the way in which meaning is particular to the individual through emotion, affect, or fantasy. ${ }^{5}$ Shakespeare uses Ophelia to expose an interplay between culture, epistemology, and psychology which constructs Hamlet's heroic subjectivity, itself understood through his logic, development, and actions informed by agency.

Shakespeare's many parallels between Hamlet and Ophelia show them speaking to the same topics as if the play were more a dialogic investigation than Hamlet's own inward solicitings suggest. ${ }^{6}$ (Their resemblance provides a plausible basis for their once mutual attraction, the reason for which often seems opaque.) Their similar feelings have sometimes been noted, ${ }^{7}$ but their cultural situations and the responses they make create their principal likeness. That Ophelia lets others construct her is obvious, but that her experience can represent Hamlet's is less evident. In a play with characters always worrying about getting knowledge, political and familial forces push both figures to use limited perspectives when judging, but both Hamlet and Ophelia reject such epistemologies. Their ambivalent and resistant responses, though different from one other, dramatically simulate an interiority within their characters. ${ }^{8}$ In the process, both figures draw us to questions about sources for psychological independence, the usefulness of knowledge, especially interior knowledge, even agency itself.

Borrowing tools provided by male parents lets both Hamlet and Ophelia make their rejections by fashioning a sense of interiority. However, as 
Ophelia resists parental intrusion, she exposes the problematic origin and nature of filial loans, particularly by examining their function in psychological processes of identification. Even if identification is protective, it may impede development. Idealized memories of his father as Hyperion pit Hamlet against Claudius even before he knows the truth. Ironically, taking each man's censure, but reserving her judgment, describes Ophelia's quiet behavior towards her brother if not also her father when she first appears. Ophelia's very first words answer her brother's arguments and pious homilies with questions, thus with politic ambiguity rather than the acquiescence often attributed to her:

Laertes: But let me hear from you.

Ophelia: Do you doubt that?

Laertes: For Hamlet, and the trifling of his favor, Hold it a fashion and a toy in blood

No more.

Ophelia: No more so?

(1.3.4-10)

Her questions open a protective space in which her thoughts remain private. Laertes continues with his pressure, but she never tells him what he wants to hear - that she will consider Hamlet's interests transient at best. Her near silence and privacy challenge Polonius' economic arguments for restricting her behavior toward Hamlet. But her quiet response also applies her father's advice. She is "something scanter of [her] maiden presence" to him even as he advises it with regard to Hamlet (1.3.122). ${ }^{9}$

Because Shakespeare's plays invest much more in father-daughter tensions than in brother-sister dynamics, we read Polonius' over-involvement in his daughter's romantic yearnings not just in terms of desires for political advancement, but also in terms of psychological needs for identification, impelling men from Egeus and Capulet through Prospero and many other Shakespearean fathers. In some ways more drained of paternal feeling than these other men, Polonius still resembles them in imagining his daughter undifferentiated from himself ("think yourself a baby. . ." [1.3.1056]). ${ }^{10}$ His energetic inquiry into the true nature concerning Hamlet's intentions displaces into politics the paternal invasiveness of his actions. His narcissistic attachment to Ophelia - paradoxically shown by his disinvestment in her as a person - thus hints at his own longings for an absent maternity, seen in other father-daughter relationships by Janet Adelman. ${ }^{11}$ 
When Ophelia adopts his tactics but resists her father's advice, she thus not only undoes his work but unearths an unfinished psychological project necessary to creating an independent, intact masculine subjectivity, ultimately for Hamlet too. To use Luce Irigaray's terms for a woman-mother, in being opaquely quiet she "remains inseparable from the work or act of man, notably, insofar as he defines her and creates his identity with her as his starting point. .. If after all this, she is still alive, she continuously undoes his work - distinguishing herself from both the envelope and the thing, ceaselessly creating there some interval, play, something in motion and un-limited which disturbs his perspective, his world, and his/its limits."12 Irigaray's emphasis on jouissance understates the investment of psychic energy - for both Ophelia and Hamlet - necessary to the steady-state maintenance of such conflict, and thus its precarious, brittle nature. ${ }^{13}$

Indeed, Ophelia's model of subjectivity emphasizes not only the psychological origins of assumed political roles, but more specifically, the fragile psychological structure organizing Hamlet's political subjectivity. As malcontent or satirist, Hamlet needs to individuate as much as Ophelia, expressed through his political role by distinguishing, creating, disturbing, even more directly than she does. Yet Hamlet's desires that his flesh would melt, and his wish to return both parents to sexual purity betray longings like those of Polonius to regain an idealized, undifferentiated state ${ }^{14}$ - with both parents, not just his mother. Much of his verbal energy derives from the conflict between his own desire for an undifferentiated family and his inability to tolerate the erotic energy circulating there.

Hamlet's commitment to action also depends largely on an ability to identify with a father he sees as a militaristic Hyperion, somehow free of sexual impulse. Because identification depends on maintaining this idealized vision, Hamlet's own sexuality disturbs him. Projecting such feelings onto Ophelia, in turn, contributes to his disgust with her. The presence of such psychological dynamics explains why he imagines his revenge could yield both the death of Claudius and the restful quiet of sleep. His thoughts about what it means "not to be" reveal longings for the kind of magical diffusion of tension associated with a pre-individuated oneness between parent and child: the same desire expressed by Polonius toward Ophelia. (Romeo and Juliet seek something similar when they famously denounce all boundaries between themselves, even their names. Shakespeare notably reassigns this kind of regressive desire for the past to Hamlet's thoughts of his parents.) That action in his most famous speech can signify both the murder of 
Claudius and suicide speaks to the impossibility of tolerating such a merger. For most of the play, to be a productive subject he thus needs both to narcissistically identify with yet recoil from his origins, not necessarily "develop" in a forward direction: a task figured by Ophelia's model of subjectivity.

The resemblance between Hamlet's and Ophelia's positions underscores the fact that, although he is finally successful, the play is ambiguously about whether positive action results from resolving either an "interior" conflict or the unilateral behavior of a poorly integrated self. ${ }^{15}$ Although rigidly Oedipal descriptions of his character and actions are long discredited, ${ }^{16}$ we still tend to rely on an assumption they bequeathed to us: that Hamlet develops beyond an entrapping intrapsychic conflict. This neurotic model supposes a reasonably intact ego which can tolerate mixtures of good and bad in others. Leverenz and others have used the language of gender in a way expressing the problem with Hamlet's ego: the play pressures him to banish one side of himself - either the threatening "female" (associated by Laertes with tears) or feeling self. ${ }^{17}$ At the political level Denmark replicates this splitting right until the play's conclusion. When Fortinbras celebrates Hamlet for having a military nature, we feel the state itself lacking integration. Rather than sustain multiple perspectives, this new society kills off conflicts, as Ophelia is killed off when, as an amalgamation of multiple voices, she impossibly attempts to move in contradictory directions. (Shakespeare reruns this process with Caesar's militaristic reduction of Antony at the end of his late tragedy.) But the play forbids us from assigning plurivocality to a distinctly female subjectivity. ${ }^{18}$ Ophelia's speech also figures the dynamic division of political perspectives in Denmark, and Hamlet's own impossible task of reconciling his divergent views of himself and his parents.

Ophelia thus becomes an emblem for arguments which challenge psychological models linking action to a coherent psychological subjectivity. Her position also counters epistemological assumptions necessary to seeing psychological growth during the drama. If she forces us to question whether individuals can by themselves resolve psychological conflict, or pressures to split off parts of themselves, then we also question whether there can be a self-learning which provides a basis for constructive action. ${ }^{19}$ Because Ophelia is in so many respects a displacement of Gertrude - herself unable to contemplate her actions - in the play's psychological dynamics, her position also reminds us that probing for certain knowledge, both in 
general and about oneself, does not necessarily foster the growth of a productive identity. (Skepticism about the usefulness of self-knowledge follows from the play's more general epistemological concerns, beginning with the opening scene, where people in darkness are having trouble getting information.)

Gertrude's unclear motives frustrate Hamlet mightily and spur him to lewd imaginings of precisely what happened - as if knowing the details of his parents' sexual relations would help him organize himself and act. Only Polonius, foolishly sure that he knows the truth about Hamlet, ever believes that certitude is useful to the degree Hamlet does early in the play. (After boasting about his ability to draw conclusions, Polonius promises the court, "I will find / Where truth is hid, though it were hid indeed / Within the center" [2.2.157-59]). In fact, Ophelia's ambiguous response to her father's wisdom makes ironic Hamlet's fervent vow two scenes later that the ghost's "commandment all alone shall live" within his brain as a kind of certain truth determining all action (1.5.103-4). Although Hamlet begins to test the ghost's authority by Act 2, it takes him until the end of the play to open room between himself and the pressure of the ghost's fixed directive. He gains release only by distancing himself from the assumption he originally shared with Polonius: that power accrues to those who are certain about others' characters. Hamlet recognizes that uncertainty should always command action: "Since no man, of aught he leaves, know what is't to leave betimes, let be" (5.2.220-22).

That the priest refers to Ophelia's "doubtful death" is ironic because Hamlet's discovery of her loss seems to aid his embrace of doubt (if only by Shakespeare's scenic juxtaposition). Although Hamlet had constructed her in terms of her maternal, recoverable knowledge, from her first interview with her father she signifies knowledge which cannot be known with certainty. She speaks ambiguously when she enters, seems a cipher when mad, and dies with "doubtful" actions which cannot confidently be deemed suicide. The lack of clarity about Ophelia's intentions rewrites Shakespeare's earlier revenge tragedy where we wonder if the mute Lavinia is really thinking words Titus attributes to her. Similarly, the verifiable action of Desdemona's elopement often strains critics' belief in the absolute virtue she claims before Emilia. These women's traits challenge male audiences to silence, or to blocked language, who then, like Titus, struggle to "wrest an alphabet / And by still practice learn to know [women's] meaning" (3.2.44 45). Titus confidently believes he can divine Lavinia's intentions: "In thy 
dumb action will I be as perfect / As begging hermits in their holy prayers" (3.2.40-41). Reversing the common misogynistic complaints about women being too open, talkative, or out of control, ${ }^{20}$ this representation in fact replicates a related convention: anxiety that the female subject's intention may elude listeners drives a desire to contain it within structures called rational.

The pattern set by Titus reappears in Hamlet, where gaining knowledge depends on being educated and male, and schooled in modes of inquiry engaging empirical and dialectical analysis towards certain conclusions about self and nature. Bernardo and Marcellus summon Horatio to the watch because he is a scholar. To Hamlet, nobility of reason makes man like an angel in apprehension yet quite specifically, a militaristic, masculine one: reason operates within "pales and forts" (1.4.28). Hamlet surprisingly shares his initial gendered assumptions with Claudius, who links "an understanding simple and unschooled" to "a heart unfortified" (1.2.96-97).

Herself a figure of doubt, Ophelia opens the play to an epistemological alternative to this aggressively searching reason, identified with the hero and other men in the play. (The play presents "masculine" reason as a prerequisite to the boundaries of a fixed or intact subjectivity, also implied in the image of "pales and forts.") Ophelia looks at knowledge using a gaze no one else, with the possible exception of Gertrude, comprehends. The play goes out of its way to disassociate her epistemological habits from the empirical exactitude Hamlet seeks. Frightened by Hamlet's mad behavior, she ascribes to him her own visual way of evaluating (emphasized in her 3.1 lament): she reports to Polonius that "He falls to such perusal of my face / As 'a would draw it" (2.1.92-93). Describing Hamlet's departure, she adds, "He seemed to find his way without his eyes / For out o' doors he went without their helps, I And to the last bended their light on me" (100-102).

Most important is her lament, " $t$ ' have seen what I have seen, see what I see" (3.1.164). Identifying others in terms of pictures, Ophelia herself resembles a kind of picture others fail to read, or to contain with their reason. Either because he needs to dismiss her ramblings or is just mistaken, Claudius articulates this practice: When she is mad, he calls her "divided from herself and her fair judgment, / Without the which we are pictures or mere beasts" (4.5.86-87, my emphasis). After Ophelia's father, Claudius is the strongest spokesman for material Denmark, and he neglects the neoPlatonic significance of picture by now associated with Ophelia's gaze and thus, the way in which pictura can bring immediate access to truth. ${ }^{21}$ Only 
Gertrude's richly pictorial dirge for Ophelia, more rhetorically directed than the speeches by its subject, similarly connects Idea to gaze.

If we assume that Claudius speaks conventional Danish wisdom about insanity transforming Ophelia into a visual icon, then he speaks for a culture generally ignoring the prophetic knowledge such figures could impart. Indeed, while himself sensitive to the disturbing power of Ophelia's ranting, the Gentleman describes her as an ignored prophet:

Her speech is nothing,

But the unshapèd use of it doth move

The hearers to collection; they yawn at it,

And botch the words up fit to their own thoughts,

Which, as her winks and nods and gestures yield them,

Indeed would make one think there might be thought,

Though nothing sure, yet much unhappily (4.5.7-13).

Shakespeare presents Ophelia much in the manner that Renaissance writers frequently saw prophets. ${ }^{22}$ However, as with his use of Margaret in the first tetralogy, the ironies they inject into political discourse draw his sympathy even if their motives do not. ${ }^{23}$ The gentleman's description puts Ophelia's prophetic, platonizing gaze at odds with Hamlet's more empirical inquiries into the nature of material reality: she materializes an epistemological paradox of being "nothing sure."24 (Hence the appropriateness of Ophelia's seeming ignorance about theatre in 3.2: like Polonius' spying "with windlasses and with assays of bias / [to] By indirections find directions out," Hamlet's brand of drama empirically tests for what happened, but inquires less into unseen intentions shaping action.) "Her speech is nothing" because it escapes certain definition and lies outside the logical analysis gendered male by the play's imagery.

Hamlet himself ultimately praises Ophelia's challenge to the material economy of politics and knowledge in Denmark. She represents an elusive, subversive excess to him, and he borrows the main trope from her own courtier-soldier-scholar speech - hyperbole - to define her meaning to him: "I love Ophelia. Forty thousand brothers / Could not with all their quantity of love / Make up my sum" (5.1.272-74). Having challenged an appetite for certainty by interrogating its psychological origins in Polonius and Hamlet, the play designates reason male, simultaneously to criticize such gendered constructions. Not knowing intensifies the drive to contain doubtful figures within explanatory structures. When not knowing is figured as an excess of signifiers, also gendered female, logic works so hard that it begins 
to exhaust its own usefulness as an element which can precisely define give boundaries to - an individual's subjectivity.

Nevertheless, people at court try to ignore Ophelia's mad, linguistically open railing, but they also attempt to shape it into something closed and circumscribed, identified by the play as male. ${ }^{25}$ Their commitment to this process indicates the threats to their own sense of psychological intactness people feel when confronted by indefinition - and thus Shakespeare's opposition between having a bounded subjectivity and one defined by epistemological uncertainty. Although he has obvious motives for saying so, Claudius reduces Ophelia's madness to an easy cause and effect: her grief "springs / All from her father's death — and now behold!" (4.5.76-77). Shakespeare parodies this kind of logical analysis - central to Hamlet's wish for containing consequences during the famous soliloquy on action in Polonius. Planning to spy on Hamlet, he tells the King," . . now remains / That we find out the cause of this effect, / Or rather say, the cause of their defect, / For this effect defective comes by cause" (2.2.100-3). Even Horatio wants Ophelia contained lest her words raise dangerous conjectures.

From the perspective of contemporary French feminism, the opposition of Claudius, Horatio, Fortinbras, and Hamlet (prior to his fifth act embrace of providence) to Ophelia's manner of signifying cannot be separated from challenges female bodies pose to gendered concepts of fixed subjectivity. In her analysis of écriture féminine, Hélène Cixous associates the female body and thus women's writing with plentitude. Similarly, in her analysis of women's jouissance, Irigaray argues that a specifically feminine language emerges from the diffuse female erotic field - a language which as a result seems crazy to the logic of reason. ${ }^{26}$ Applying Irigaray's construction to the mad Ophelia risks gendering mental illness - neither Shakespeare's canon nor experience claims that Ophelia's ramblings are a specifically feminine voice. However, Irigaray's model can help us explain why Hamlet is so concerned about Ophelia's body. Men try to manage it much as they try to control or circumscribe the meaning of her speech. In the masculine discourse of the play, reason and the logical closure of meaning indicate, to rephrase Claudius' words, a unified self and judgment. The men in this tragedy have confidence that they are intact when they believe themselves logical. They struggle to ignore or contain Ophelia not just because her speech, but her body itself, resists the kind of logical closure they find necessary to their own experience of feeling bounded. 
Ophelia's words leave her open to Hamlet's double entendres. His jokes point to cultural connections between female speech, female bodies, indefinition, and danger:

Hamlet: Do you think I meant country matters?

Ophelia: I think nothing, my lord.

Hamlet: That's a fair thought to lie between maids' legs.

Ophelia: What is, my lord?

Hamlet: Nothing.

Because Hamlet's joke introduces the Renaissance equation between "nothing" and female genitalia, the Gentleman's later assertion that "her speech is nothing" initially marks her kind of speech as specifically feminine. More importantly, it shows this discourse of indefinition, and the alternative subjectivity (with unfixed boundaries) which follows from it, to be threatening, even politically dangerous. For example, when afraid of a movement against him, the king projects Ophelia's character onto the growing number of people favoring Hamlet: "the distracted multitude / Who like not in their judgment, but their eyes" (4.3.4-5). Taking in information visually, like Ophelia, distracted as she appears in the next scene, this group initially seems strong. But the king is ironically wrong: they ultimately have nothing to do with Hamlet's triumph; silent in the last act, they disintegrate like the woman with whom they are metaphorically joined. The play identifies the forces of rebellion with Ophelia's body which, during madness, becomes an efficient emblem of related challenges to male authority: nothing is a political threat constructed by Claudius; a source of epistemological resistance to Hamlet and Fortinbras; and a provocation exposing psychological longings for interior richness in Polonius and the Prince. Shakespeare more directly criticizes this practice of mapping political and psychological oppositions with the female body in Antony and Cleopatra, where Caesar thinks of loyalty to Pompey in terms of metaphors associated with Cleopatra's "feminizing" effect on Antony: "This common body, / Like to a vagabond flag upon the stream, / Goes to and back, lackeying the varying tide" (1.4.44-46).

Ophelia's resistant discourse eroticizes these oppositions and challenges. But her disjointed speeches do not define a feminine language so much as they interrogate the related economies of object relations and a readiness to act which mark Hamlet's "developed" subjectivity in the play. Expressive 
of her body, many of Ophelia's voices are readily accessible to a postFreudian eye. She materializes, sexualizes, and internalizes lost objects. Not having responded to Hamlet's entreaty after his soliloquy on action, she is later "the owl [that] was a baker's daughter" - the daughter Jesus turned into an owl because she did not respond generously to his request for bread. ${ }^{27}$ She tells a parable of losing a man for granting sexual favors: "Quoth she, 'Before you tumbled me, / You promis'd me to wed' / He answers: / 'So would I ha' done, by yonder sun, / An thou hadst not come to my bed"' (4.5.63-67). Her madness shows her still a good pupil to Polonius, and Hamlet too: she seems to assume, like her father, that a maiden too free with her presence will lose her love object, and perhaps imagines she herself was that way before her father's warnings. Yet her madness reveals her overdetermined plight: at the same time men ask her to withhold, she hears them asking women to feed them - if not as the baker's daughter, with food, with the nurturing action implied in the primitive metaphorics of not separating. This dynamic exposes a source of seeing the female body as dangerous, as representing a kind of thought needing logical control. It argues that when men see an emotionally withholding woman, they respond as if they are being denied narcissistic affirmation. Rage erupts, generated by fears of subjective indefinition.

By raising the possibility that subjects may not be coherently defined, Shakespeare also uses Ophelia to question whether agency actually exists, or serves as a marker of subjectivity. The doubts surrounding Ophelia's death not only present her as a figure of uncertainty, but also raise questions about whether agency itself can define subjectivity.

Gertrude's motives when speaking about Ophelia's death are themselves uncertain. She could be seeking to quietly absolve herself; she may be trying to absolve Ophelia of suicide out of love for her; or she might be struggling to make sense of Hamlet's plight. Her judicial oration simultaneously deliberates about choice and agency for all three of them. The images in her argument provide all that we see of the courtroom deliberations satirized immediately after by the gravediggers, who themselves interrogate agency. Gertrude's argument for an accidental cause, in which case Ophelia could not be responsible, uncomfortably, perhaps unconsciously, expiates her own motives in marrying Claudius. (Driven by desire, perhaps by impulses from which she turns her eyes, Gertrude may view herself as lacking agency.) Because it is a speech about loss, we can also read it as a displacement of her attitudes towards the situation of her son, now lost to 
her on the way to England and also, in several emotional senses. Shakespeare undermines agency, a crucial element to subjectivity based in logic and certainty.

By painting Ophelia as Flora picking phallic flowers, by having the weight of female clothing speed the drowning, Gertrude seeks to feminize her absolution of Ophelia from responsibility. But the structure of the play and its insistent parallels between Ophelia and Hamlet fold Gertrude's assumptions about différance into patterns describing agency and heroic subjectivity in general. Gathering her fantastic garlands, Ophelia is actually the tragedy's second gardener with "grosser named" things. Hamlet has desired but as yet has not picked things "gross in nature" from his metaphoric garden. Were he able to do so he would wear the crown, a parody of which exists in the "crownet weeds" Ophelia weaves and wears. ${ }^{28}$ Transforming phallic weeds into a crown aptly comments on the conflicts which fuel Hamlet's energy: between idealized identification with the father through action and the sense of corruption this identification engenders.

Gertrude's oratory finds pictorial equivalents connecting agency and psychological dynamics for both Hamlet and Ophelia. Ophelia's ramblings about the white bearded man with the flaxen poll perhaps suggested to the Queen the "hoary leaves" of the male figured willow overhanging the brook. Unmistakably a paternal image, it is, according to Gertrude, responsible for Ophelia's death because its "envious sliver broke." The image argues that competition between father and child set the tragedy in motion. Invoking the comic model Shakespeare borrows for the relationship between Polonius and Ophelia, the competitive image also reminds us that the problem engendered by Hamlet's parents is a displaced version of that pattern: Claudius' envy of his brother plays out a frightening real-life version of the son's competition with his father, and has not only set Hamlet's tragedy in motion, but intensified its psychological depth and intensity. ${ }^{29}$ Perhaps reflecting her own sense of what it is like to be swept along by currents of power, Gertrude depicts such victims as essentially passive in a scene with pictorial elements making depersonalized forces of paternal economies the cause of disaster. Gertrude pushes cause so deeply into a psychological past that she almost succeeds in absolving present responsibility. Othello, to whom "chaos is come again" when he doubts Desdemona, similarly shows Shakespeare rooting proximate cause in a time so distant that effect almost seems to precede cause and choice seems to have been long overdetermined, limiting present agency. ${ }^{30}$ 
Actually, Gertrude suggests Ophelia shrinking from the foreground or at least, de-emphasizes her unique subjectivity. In fact, as "a creature native and indued / Unto that element," Ophelia does not dominate or organize the landscape as she does in Millais' famous version of the scene. Flora has little or short-lived power and no agency within her kingdom: "her garments, heavy with their drink, / Pulled the poor wretch from her melodious lay" (4.7.182-83). Echoing Hamlet's sweet bells which jangle out of time, Ophelia's melody fades because she literally absorbs her environment, as she has metaphorically done with regard to parental advice. Hamlet certainly makes a more conscious and clear choice than Ophelia to confront his own death, but Gertrude's parallels between him and Ophelia argue that the agency and cause of action lie outside him.

Shakespeare thus assimilates Gertrude's rhetoric about Ophelia's death into a larger argument (but not conclusion) about his tragic hero. Hamlet may not be a fully realized subject - if we share the view, implicit in the first clown's satire, that subjects take actions wittingly, with an intention they shape. The clown sarcastically notes that if water reaches up to and drowns its victim her agency would not be an issue, relieving her of responsibility (5.1.15-20). He jokingly wonders, "How can [it not be suicide, prohibiting Christian rites], unless she drowned herself in her own defense?" (5.1.6-7). The clown finds both events logically impossible because he firmly believes that people govern their circumstances, and acts (like drowning) unambiguously indicate the presence of a coherent individual agency.

But the clown's assumptions are wrong, at least by what Katharine Maus has shown to be the measure of Renaissance courtrooms. ${ }^{31}$ Hamlet can finally act because he recognizes he would be defending both himself and Denmark from an evil "canker"; water may not have come to Ophelia and her action is not self-defense, but another deadly liquid does come to Hamlet and Gertrude. Agency and intention do not function efficiently for either Hamlet or Ophelia and if these are principal parameters defining subjectivity, neither character meets the test.

Must they? Shakespeare's iterated parallels between the psychological dynamics of Hamlet and Ophelia, the deliberative orations made by Hamlet, Ophelia and Gertrude, together open the play to more than one means of defining subjectivity. They show the play engaged with the continual historical project of defining identity itself. Because Hamlet's view so occupies the play, subjectivity initially seems a space rooted in knowledge, certainty, and concepts of agency. It shows itself in resolutions of internal conflict, consis- 
tent and useful identification with others, and action springing from a coherent internal identity. However, the play also challenges both the usefulness of these formulations and their very possibility. Still, Shakespeare does not necessarily bury subjectivity itself while interrogating paradigms through which the idea of it circulates. As Maus warns, we should not conflate personal inwardness with related but distinct concepts of uniqueness, autonomy, a unified self, individualism, and others. ${ }^{32}$ Francis Barker argues that Hamlet "utters a first demand for the modern subject," even though he considers the concept of subjectivity anachronistic. ${ }^{33}$ Even as post-modern a critic as Linda Charnes sees Shakespeare's plays positing a "powerful [human] desire for autonomy - however fantasmatic."34 By using Ophelia to expose origins and display the erotic economies of family, gender, and politics, the play interrogates its own longings, and its participation in defining subjectivity. (Hence it can invite both psychoanalytic approaches which envision essential, if dynamically engaged selves, such as the object relations derived methods I have used in this essay, and those which wonder if such selves are more than cultural constructions, including some of the feminist theorists I have cited.) But like Ophelia, the tragedy never rejects the assumptions or tools provided by the cultural economy it represents, even if this means occasionally aligning Hamlet with Claudius or Polonius, as we have seen. Thanks to the voices of Ophelia and Gertrude, the play has much in common with arguments about subjectivity, even if Hamlet does not. ${ }^{35}$

State University of New York, Geneseo

\section{Notes}

1. The most direct challenges to arguments that subjectivity existed discursively in the early modern period are from Catherine Belsey, The Subject of Tragedy: Identity and Difference in Renaissance Drama (New York: Methuen, 1985); Patricia Fumerton, Cultural Aesthetics: Renaissance Literature and the Practice of Social Ornament (Chicago: University of Chicago Press, 1990); Francis Barker, The Tremulous Private Body: Essays in Subjection (London: Methuen, 1984); Peter Stallybrass, "Shakespeare, the Individual, and the Text," in Cultural Studies, ed. Lawrence Grossberg, Cary Nelson, Paula Trecchler (London: Routledge, 1992), pp. 593-612, in an Althusserian analysis; and Linda Charnes, Notorious Identity: Materializing the Subject in Shakespeare (Cambridge, MA: Harvard University Press, 1993). During his discussion of Hamlet, Lars Engle recasts post-modern theories in terms of American pragmatism to mediate between arguments that Hamlet owns his own subjectivity and opposing views that the subject's position is a product of intersecting discourses, in Shakespearean Pragmatism: Market of his Time (Chicago: 
University of Chicago Press, 1993), pp. 63-73. Christy Desmet presents the debate in terms of character and its function within the history of rhetoric in Reading Shakespeare's Characters: Rhetoric, Ethics and Identity (Amherst: University of Massachusetts Press, 1992). All references to Hamlet are taken from the text in David Bevington, ed., The Complete Works of Shakespeare (New York: Harper Collins, 1992).

2. C. L. Barber and Richard Wheeler, The Whole Journey: Shakespeare's Power of Development (Berkeley: University of California Press, 1986), p. 267.

3. Desmet, p. 34, argues that as a figure of prudentia, Ophelia presents speeches which force us to judge Hamlet prudentially.

4. Julia Kristeva, "Interview with Xavière Gauthier," in Elaine Marks and Isabelle de Courtiviron, eds. New French Feminisms (New York: Schocken Books, 1981), p. 86.

5. Nancy J. Chodorow, "Gender as a Personal and Cultural Construction," Signs, 20 (1995), 516-544.

6. With the term "investigation" I am specifically suggesting that Hamlet participates in the humanist tradition of drama as rhetorical inquiry, outlined by Joel Altman, The Tudor Play of Mind: Rhetorical Inquiry and the Development of Elizabethan Drama (Berkeley: University of California Press, 1983), especially pp. ix-xvii. See also Marion Trousdale, Shakespeare and the Rhetoricians (Chapel Hill: University of North Carolina Press, 1982), which sees inquiry concluding in indeterminacy.

7. Some of these - following fathers' edicts, imperfectly understanding the court's forces, madness, isolation, and feeling betrayed - have been noted by Sandra K. Fischer, "Hearing Ophelia: Gender and Tragic Discourse in Hamlet," Renaissance and Reformation / Renaissance et Réforme, n.s. 14 (1990), p. 2.

8. In this context I am using "interiority" to mean neither coherent subjectivity nor heroic individualism, but rather a sense of psychological probing of, and struggle with the self. Subjectivity, self, and identity are not necessary requirements for this essentially discursive activity in either post-modern or psychoanalytic models of the subject.

9. Her terse vow of obedience to Polonius, like her brief questions to Laertes, initially look like submission. Yet "I shall obey" similarly provides a means for ending and evading Polonius' harangue, especially if we consider that defense against parental intrusion requires discourse still less direct than that needed to fend off a brother. In fact, despite Ophelia's almost pathetic soliciting for paternal approval at times in 1.3, Frances Barber considers her character strong, even hearing in Ophelia's self-effacing conclusion a note of defiance. See Barber, "Ophelia in Hamlet," in Russell Jackson and Robert Smallwood, eds., Players of Shakespeare II: Further Essays in Shakespearean Performance by Players with the Royal Shakespeare Company (New York: Cambridge University Press, 1988), p. 141. Juliet's more emotionally extreme strategies anticipate Ophelia's, thus further suggesting calculation rather than complete capitulation. Desperately seeking Capulet's approval as he condemns her, she beseeches him on her knees. When she prostrates herself a second time in the same scene, seeming desperation is actually defiance. Both figures' glib, possibly angry compliance effectively cuts off discussion while erasing indications of anger. 
10. It may initially seem that Polonius would be imagining himself a baby if unconsciously desiring a lack of differentiation. However, since Polonius regularly projects himself into his children's positions - as when enjoining Laertes towards caution in his travels - it is likely that in imagining Ophelia a baby he imagines himself one too. Theseus' remark in A Midsummer Night's Dream that Hermia should be to Egeus as a "form in wax, / By him imprinted" (1.1.49-50) reminds us that the over-controlling nature of many Shakespearean fathers derives from a failure, involving the parent, to separate himself so that individuation in the child can occur.

11. Adelman, Suffocating Mothers: Fantasies of Maternal Origin in Shakespeare's Plays, Hamlet to The Tempest (New York: Routledge, 1992), passim.

12. Luce Irigaray, An Ethics of Sexual Difference, trans. Carolyn Burke and Gillian C. Gill (Ithaca: Cornell University Press, 1993), p. 10.

13. Irigaray hints at such demands, but in political rather than intrapsychic terms, as when she says, "One must assume the feminine role deliberately, which means already to convert a form of subordination into an affirmation, and thus to begin to thwart it." See The Sex Which is Not One, quoted in Patricia Parker, Literary Fat Ladies: Rhetoric, Gender, Property (New York: Methuen, 1987), p. 8.

14. For a Chodorow influenced discussion of men needing to deny their mother's sexual role in their creation, see Adelman on Hamlet, pp. 11-37, especially, pp. 22-24, 32-35.

15. I am borrowing the latter term from ego psychology and also from Kohutian self-psychology. See, for example, Heinz Kohut and Emest Wolf, "The Disorders of the Self and their Treatment: An Outline," International Journal of Psycho-Analysis, 59 (1978), 413-425, especially pp. $418-419$.

16. For the best discussion of the problems with seeing Hamlet as having an Oedipal "complex," see Meredith Skura, The Literary Uses of the Psychoanalytic Process (New Haven: Yale University Press, 1978), pp. 42-50.

17. See David Leverenz, "The Woman in Hamlet: An Interpersonal View," Signs, 4 (1978), pp. 282, 303; David Rosen, The Changing Fictions of Masculinity (Champaign: University of Illinois Press, 1993), pp. 78-79. Bert States, Hamlet and the Concept of Character (Baltimore: Johns Hopkins University Press, 1992), p. 17, disputes the notion that Hamlet's unpredictable, violent, and incoherent moves indicate a "diffuse" personality. States may be right to see Hamlet as "all of a character," but consistency of dramatic character is not the same as having a cohesive self or intact ego.

18. Using Irigaray, Fischer, p. 2, assigns plurivocality to a distinctly female subjectivity in the play.

19. When I refer to psychological conflict I am relying on a neurotic model of the subject: splitting uses a narcissistic model originating in ego psychology and its later development in the work of Koemberg on borderline personalities and Kohut on narcissistic disorders of the self. In Shakespeare the Actor and the Purposes of Playing (Chicago: Chicago University Press, 1993), Skura traces the impact of needing affirmation on representations of acting throughout the canon. For her discussion of Hamlet, see pp. 140-142, 149-152. 
20. See Parker on the identification of "wayward women and wayward and copiously fattened texts," p. 35 and pp. 8-35; or Desmet, pp. 134-163.

21. Cf. Ben Jonson, Discoveries (1522-1524): "Whosoever loves not Picture, is injurious to Truth: and al the wisdom of Poetry. Picture is the invention of Heaven: the most ancient, and most a kinne to Nature," in C.H. Herford, Percy and Evelyn Simpson, eds., Ben Jonson, vol. 8 (Oxford: Clarendon Press, 1947), p. 610. Also see the visual nature of Sidney's neo-Platonic "fore-conceit" in his Defense of Poetry.

22. For attitudes towards political prophecy, see Howard Dobin, Merlin's Disciples: Prophecy, Poetry, and Power in Renaissance England (Stanford: Stanford University Press, 1990).

23. See Phyllis Rackin, Stages of History: Shakespeare's English Chronicles (Ithaca: Cornell University Press, 1990).

24. Desmet calls her a figure of Prudence for an ability to create a persuasive portrait of Hamlet by "bringing both past and future into the present moment" (p. 33), identifying in rhetorical terms the prophesying function Ophelia shares with an alternatively configured group of women, including Calphurnia and Cassandra (in plays temporally close to Hamlet), and women from the histories. Ophelia also epitomizes figures whose roles critique the secular present by recalling medieval visions of power and learning. Gloucester learns to "see feelingly," with the affect accompanying Ophelia's declaration, "O, woe is me / T'have seen what I have seen, see what I see" (3.1.160-61). For Shakespeare's use of medieval theology to critique secular, materialist Renaissance conceptions of power, see John Cox, Shakespeare and Dramaturgy of Power (Princeton: Princeton University Press, 1989).

25. Continuing to gender epistemologies, Shakespeare has only Gertrude suspicious of just how significant Ophelia's ramblings might be: "Each toy seems prologue to some great amiss, / So full of artless jealousy is guilt, / It spills itself in fearing to be spilt" (4.5.18-20).

26. On Cixous, see Ann Rosalind Jones, "French Theories of the Feminine," in Making a Difference: Feminist Literary Criticism, eds. Gayle Greene and Coppélia Kahn (New York: Methuen, 1985), p. 88; for Irigaray, see This Sex Which is Not One, trans. Catherine Porter (Ithaca: Cornell University Press, 1985), pp. 101-103.

27. See note to 4.5.42 in The Riverside Shakespeare, eds. G. Blakemore Evans et al. (Boston: Houghton Mifflin, 1974), p. 1173.

28. Charlotte Otter examines contemporary attitudes towards the weeds and notes that "Ophelia is garlanded in death with [plants which would have seemed like] floral genitalia." See "Ophelia's 'Long Purples' or 'Dead Men's Fingers,"” Shakespeare Quarterly, 30 (1979), p. 398. Sexually evocative, Ophelia's weeds display all too obviously the hidden dynamics controlling the Danish crown - another script the play's courtiers want to ignore and the examination of which engenders a sense of self-corruption and disgust for Hamlet.

29. In this remark I am borrowing the assumptions of Skura, The Literary Uses of the Psychoanalytic Process, pp. 42-50, who cogently demonstrates that Hamlet's environment has an Oedipal configuration even though he himself does not specially possess an Oedipal "complex." 
30. For Shakespeare's rhetorical figuration of effect preceding cause, see Joel Altman, “'Preposterous Conclusions': Eros, Enargeia, and the Composition of Othello," Representations, 18 (1987), 124-157. Adelman, pp. 65-66, 70, renders psychoanalytically the very early causation of Othello's tragedy in the unrecoverable, very early processes of separation and responses to maternal sexuality.

31. Maus argues that Renaissance courts indeed distinguished between intention and behavior. See her discussion of Isabella in Inwardness and Theater in the English Renaissance (Chicago: University of Chicago Press, 1995), p. 180.

32. Maus, p. 212.

33. Barker, p. 34.

34. Charnes, p. 151.

35. An earlier version of this essay was presented at the Seminar on "Gender and Formalism" during the 1990 meetings of the Shakespeare Association of America in Philadelphia. I am grateful to Gabriele Bernhard Jackson and the members of the Seminar for their responses to an earlier draft. 